ББК 63.4

$$
\begin{gathered}
\text { Организация конференции и издание материалов проведены } \\
\text { при финансовой поддержке Российского фонда фундаментальных исследований, } \\
\text { проект № 19-09-20008 }
\end{gathered}
$$

Утверждено к печати Ученым советом ИИМК РАН

Редакционная коллегия тома II: А. В. Поляков, Е. С. Ткач (отв. редакторы), М. Т. Кашуба, Л. Б. Кирчо, Е. А. Черлёнок, В. Я. Стёганцева, А. И. Климушина

Рещензенты: д. и. н. Л. Б. Вишняцкий, д. и. н. А. А. Выборнов

Программный комитет конференции: академик РАН, д. и. н., проф. М. Б. Пиотровский (Государственный Эрмитаж, почетный председатель); д. и. н. В. А. Лапшин (ИИМК РАН, председатель); д. и. н. А. В. Головнёв (МАЭ РАН, сопредседатель); д. и. н. В. А. Дергачёв (Высшая антропологическая школа, Молдова, сопредседатель); д. и. н. И. Ф. Попова (ИВР РАН, сопредседатель); академик АН Республики Узбекистан, д. и. н., проф. Э. В. Ртвеладзе (сопредседатель); к. и. н. А. В. Поляков (ИИМК РАН, зам. председателя); к. и. н. В. А. Алёкшин (ИИМК РАН, зам. председателя); д. и. н. Ю. Е. Берёзкин (МАЭ РАН); Dr., Prof. Н. Бороффка

(Германский археологический институт, Германия); В. С. Бочкарёв (ИИМК РАН);

Dr. Э. Кайзер (Свободный университет Берлина, Германия); к. и. н. М. Т. Кашуба (ИИМК РАН); д. и. н. Л. Б. Кирчо (ИИМК РАН); к. и. н. А. В. Кияшко (Южный федеральный университет); к. и. н. П. Ф. Кузнецов (СГСПУ); к. и. н. Н. М. Малов (СНИГУ); к. и. н. В. П. Никоноров (ИИМК РАН); Ю. Ю. Пиотровский (Государственный Эрмитаж); д. и. н., проф. Д. Г. Савинов (Институт истории СПбГУ); к. и. н. В. Н. Седых (Институт истории СПбГУ); к. и. н. Н. Н. Скакун (ИИМК РАН); к. и. н. Н. Ф. Соловьёва (ИИМК РАН); к. и. н. А. И. Торгоев (Государственный Эрмитаж); к. и. н. Е. А. Черлёнок (Институт истории СПбГУ)

Организационный комитет конференции: к. и. н. А. В. Поляков (ИИМК РАН, председатель); к. и. н. В. А. Алёкшин (ИИМК РАН, зам. председателя); В. С. Бочкарёв (ИИМК РАН); к. и. н. М. Т. Кашуба (ИИМК РАН); д. и. н. Л. Б. Кирчо (ИИМК РАН);

А. И. Климушина (ИИМК РАН, отв. секретарь); к. и. н. В. П. Никоноров (ИИМК РАН); Ю. Ю. Пиотровский (Государственный Эрмитаж); В. Я. Стеганцева (ИИМК РАН); В. В. Терёхина (ИИМК РАН, МАЭ РАН, отв. секретарь); к. и. н. Е. С. Ткач (ИИМК РАН); И. Ж. Тутаева (Государственный Эрмитаж); к. и. н. Е. А. Черлёнок (Институт истории СПбГУ)

Древности Восточной Европы, Центральной Азии и Южной Сибири в контексте связей и взаимодействий в евразийском культурном пространстве (новые данные и концепции): Материалы Международной конференции, 18-22 ноября 2019 г., Санкт-Петербург. Т. ІІ. Связи, контакты и взаимодействия древних культур Северной Евразии и цивилизаций Востока в эпоху палеометалла (IV-I тыс. до н. э.). К 80-летию со дня рождения выдающегося археолога В. С. Бочкарёва. - СПб.: ИИМК РАН, Невская Типография, 2019. - 287 с.

ISBN 978-5-907053-35-9

DOI 10.31600/978-5-907053-35-9 


\title{
ELEMENTAL COMPOSITION OF THE TOOLS FROM THE SOSNOVAYA MAZA HOARD OF THE LATE BRONZE AGE
}

Vasiliy M. Retivov*, Anastasiya Yu. Loboda ${ }^{\star}$, Elena Yu. Tereshchenko*, Irina A. Kamenskikh ${ }^{\star \star}$, Natal'ya I. Shishlina ${ }^{* *}$

${ }^{*}$ Kurchatov Institute, Moscow, Russia; ${ }^{* *}$ Moscow State University, Moscow, Russia;

*** State Historical museum, Moscow, Russia

Keywords: Sosnovaya Maza hoard, elemental analysis, inductively coupled plasma mass spectrometry, MS-ICP.

The elemental composition of the sickles from the Sosnovaya Maza hoard was studied using inductively coupled plasma mass spectrometry (MS-ICP). The analysis of the composition was conducted on 57 specimens from the collection of the State Historical Museum and 3 items from the collection of the Saratov Regional Museum of Local History. Reference samples included sickles and knives from Late Bronze Age sites of the Urals and Kazakhstan. The main components of the alloys of the Sosnovaya Maza hoard specimens are copper (91.30-99.19\%) and iron (0.02-7.85\%). Also, in the alloys there were micro- and trace impurities of the following elements: $\mathrm{Ni}, \mathrm{Zn}, \mathrm{As}, \mathrm{Pb}, \mathrm{Co}$, and Se. Statistical processing of the MS-ICP results made it possible to identify two types of direct correlations between the contents of individual alloy components over the entire assemblage studied. Investigation of alloys of the reference samples showed that the closest composition to the Sosnovaya Maza items is demonstrated by the sickle from the Alekseyevka site in Kazakhstan.

\section{ТРАСОЛОГИЧЕСКОЕ ИССЛЕДОВАНИЕ «СЕРПОВ» ИЗ КЛАДА СОСНОВАЯ МАЗА}

\author{
А. Ю. Лобода ${ }^{\star}$, Н. Н. Шишлина ${ }^{\star *}$ \\ ${ }^{\star}$ НИЦ «Курчатовский институт», Москва, Россия; ${ }^{*}$ Государственный исторический \\ музей, Москва, Россия
}

DOI: 10.31600/978-5-907053-35-9-194-196

Ключевые слова: клад Сосновая Маза, трасологический анализ.

Исследуемый клад был найден в 1901 г. в Хвалынском р-не Саратовской обл. В коллекции Государственного исторического музея хранится 68 изделий клада. Два серпа и кельт хранятся в Саратовском областном музее краеведения (СОМК), один серп и кинжал находятся в Хвалынском музее.

Исследованием орудий, входящих в состав Сосново-Мазинского клада, в разное время занимались Н. А. Аванесова (1991), В. А. Дергачёв и В. С. Бочкарёв (2002), элементный состав изделий изучался Е. Н. Черных (1966).

В данной работе представлены результаты трасологического исследования 42 серпов из коллекции ГИМ и двух серпов из собрания СОМК. В литературе орудия такого типа известны как «косари-серпы сосново-мазинского типа». Это широкое однолезвийное орудие с изогнутым обухом с бортом и прямым лезвием. Пятка четырехугольной формы, как правило, не выделена, в центре - округлое отверстие или штырь.

Трасологический анализ серпов выявил ряд следов на поверхности предметов, которые были отнесены к трем технологическим этапам. Литейные дефекты (каверны, наросты, пористость) относятся к этапу изготовления изделий. Проковка лезвия, облоя и литейных дефектов, шлифовка лезвия - к следам постлитейной обработки. Также была выявлена третья группа следов, отражающая вероятное использование серпов, - зарубки на лезвиях, трещины, в одном случае - следы незаконченного намеренного разрубания серпа, возможно, для вторичного использования. 
По качеству отливки все исследованные изделия можно разделить на две группы. 1) 30 серпов из собрания ГИМ и один серп из коллекции СОМК можно охарактеризовать как добротные отливки с незначительными дефектами. Наросты, каверны и непроливы на этих серпах не искажают описанную выше общую для серпов конструкцию и не оказывают сильного влияния на их прочность и способность сопротивляться деформациям. 2) 13 серпов из собрания ГИМ и один серп из коллекции СОМК имеют крупные наросты, непроливы и дефекты. Их можно отнести к литейному браку и считать полуфабрикатами (Дергачёв, Бочкарёв 2002), приготовленными к последующей переплавке.

Преимущественно именно на серпах первой группы фиксируются следы дальнейшей проковки, заточки и предположительного использования в качестве рубящих орудий. Однако зафиксировано несколько исключительных экземпляров. Так, на одной отливке серпа высокого качества без дополнительной обработки видны следы вероятного использования (ГИМ, оп. А307/24) (рис. 1, a). Самым ярким исключением является серп из коллекции СОМК (КП СМК 38584/2) (рис. 1, б). Этот серп представляет собой широкое однолезвийное орудие, аналогичное другим изделиям, однако его клинок сильнее изогнут по длинной стороне, а общая толщина изделия несколько выше обычной. На обухе данного серпа отсутствует выступающий борт, а на пятке нет ни отверстия, ни замещающего его в некоторых случаях штыря. От края пятки вглубь проходят несколько сквозных трещин, поверх которых на обеих сторонах серпа на всей поверхности фиксируются следы интенсивной проковки. Несмотря на наличие значительных дефектов, на лезвии данного изделия зафиксирован ряд зарубок, указывающих на использование серпа после проковки.

Отметим, что именно ковка применяется в качестве основной технологической операции по обработке отлитых изделий в серпах Сосново-Мазинского клада. Следов опиливания
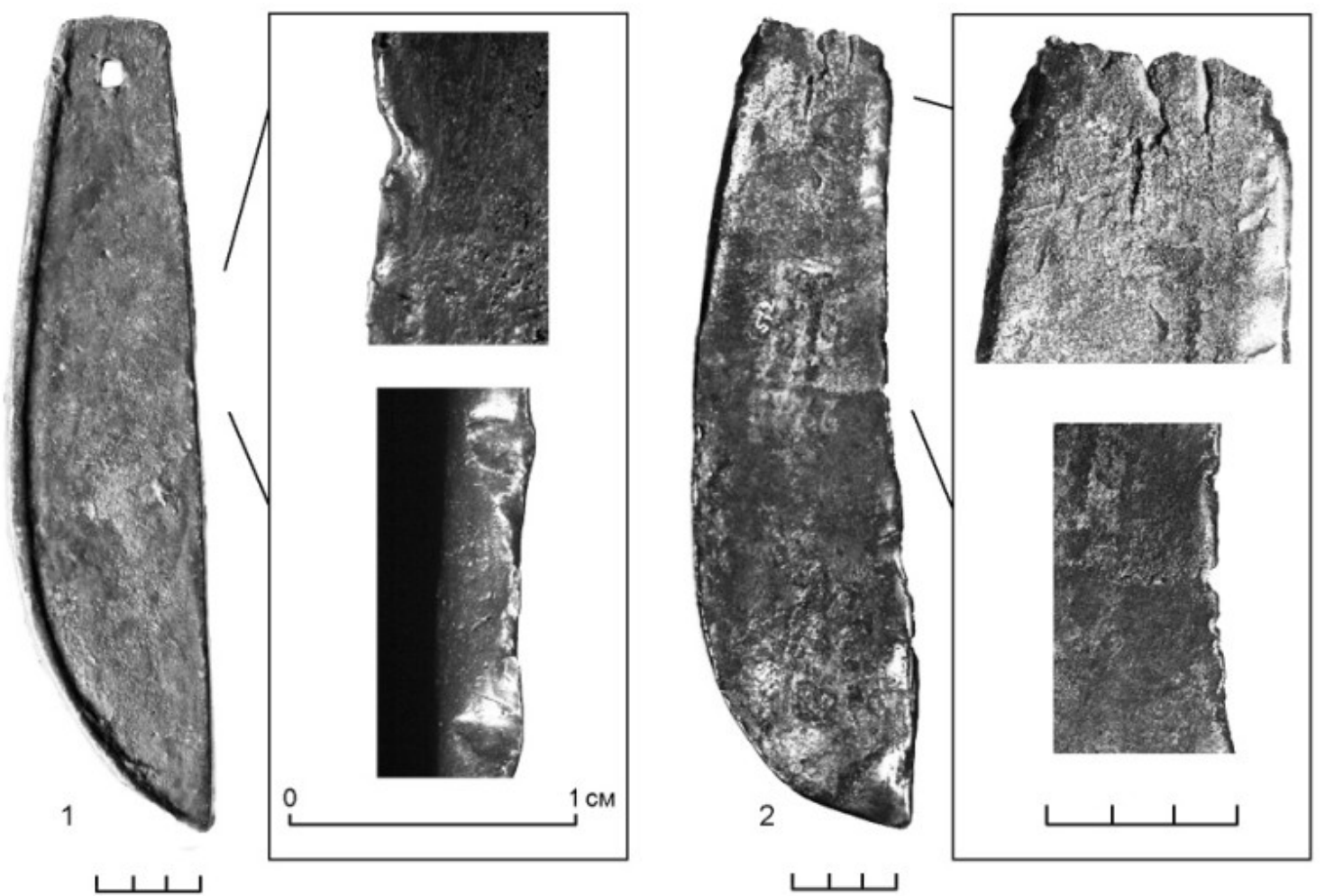

Рис. 1. Сосново-Мазинский клад: 1 - серп из собрания ГИМ (оп. А307/24), следы вероятного использования; 2 - серп из собрания СОМК (КП СМК 38584/2), следы вероятного использования 
или обсечения облоя на серпах не обнаружено, во всех случаях постлитейной обработки литьевые дефекты прокованы к поверхности клинка.

Проковка лезвия качественных серпов перед использованием и применение укрепленной ковкой бракованной заготовки демонстрирует преобладание этой технологии среди методов постлитейной обработки металла в мастерской, изготовившей данный клад, а также сознательное использования ковки мастерами не просто для придания нужной формы изделию, а, в первую очередь, для улучшения механических свойств предметов.

\section{Литература}

Аванесова Н. А. 1991. Культура пастушеских племен эпохи бронзы Азиатской части СССР. Ташкент.

Дергачёв В. А., Бочкарёв В. С. 2002. Металлические серпы поздней бронзы Восточной Европы. Кишинёв.

Черных Е. Н. 1966. О химическом составе металла клада из Сосновой Мазы // КСИА. Вып. 108. C. $123-131$.

\section{USE-WEAR ANALYSIS OF “SICKLES” FROM THE SOSNOVAYA MAZA HOARD}

Anastasiya Yu. Loboda ${ }^{\star}$, Natal'ya I. Shishlina $^{\star *}$

${ }^{\star}$ Kurchatov Institute, Moscow, Russia; ${ }^{* *}$ State Historical museum, Moscow, Russia

Keywords: Sosnovaya Maza hoard, tracewear analysis.

Use-wear analysis of "sickles" from the Sosnovaya Maza hoard revealed traces on the surface of these objects that were assigned to three technological stages of their life histories. Casting defects (caverns, excrescences, porosity) belong to the stage of casting of the products. Forging of the blade, burrs and casting defects, grinding of the blade are traces of post-processing. A third group of traces has also been distinguished reflecting probably the stage of the use of the sickles: notches on the blades, cracks, in one case, traces of cutting of the blade. The working of the sickles after casting is better observable on objects with minor casting defects; however, a number of exceptions were recorded. The forging of high-quality sickle blades before their use and the employment of reinforcing forging of defective blanks demonstrates the predominance of this technique over the other methods of post-casting metal processing in the workshop where the objects from this hoard were manufactured. Also the intentional use of forging, not in order just to shape the desired product, but, primarily, to improve its mechanical properties is observable.

\section{ОБ ОДНОМ ТИПЕ МЕТАЛЛИЧЕСКИХ КИНЖАЛОВ ЭПОХИ ПОЗДНЕЙ БРОНЗЫ - РАННЕГО ЖЕЛЕЗА СЕВЕРО-ВОСТОЧНОГО КАВКАЗА}

\section{О. В. Сычёва}

Институт истории материальной культуры РАН, Санкт-Петербург, Россия

DOI: 10.31600/978-5-907053-35-9-196-198

Ключевые слова: бронзовый век, бронзовые кинжалы, Ярык-су, Дагестан, оружие, кобанская культура, Сержень-Юрт.

В могильниках Северо-Восточного Кавказа, которые датируются временем перехода от ПБВ к РЖВ, были найдены своеобразные кинжалы, которые по целому ряду признаков отличаются от кинжалов кобанской культуры. Недавно серия этих кинжалов пополнилась за счет находки с берега р. Ярык-су близ сел. Симсир, Казбековского р-на Республики Дагестан (на границе с Ножай-Юртовским р-ном Республики Чечня). 